\title{
Prevalence of antibody to hepatitis $C$ virus in an isolated Canadian Inuit settlement
}

\author{
GY MINUK, MD, FRCPC, LE NICOLLE, MD, T GAUTHIER, J BRUNKA
}

\begin{abstract}
GY Minuk, LE Nicolle, T Gauthier, J Brunka. Prevalence of antibody to hepatitis C virus in an isolated Canadian Inuit settlement. Can $J$ Infect Dis 1991;2(2):71-73. Sera from 720 inhabitants of Baker Lake, Northwest Territories, a community with high rates of hepatitis A and $\mathrm{B}$ infection, were tested for antibody to hepatitis $\mathrm{C}$ virus by commercial enzyme-linked immunosorbent assay. Only two individuals (0.3\%) were positive, a 63-year-old female and an unrelated 10-year-old male. Neither individual was at increased risk of hepatitis C virus exposure. The results of this study indicate that hepatitis $\mathrm{C}$ virus infection is no more common in this northern Canadian Inuit settlement than it is in the blood donor population of southern Canada.
\end{abstract}

Key Words: Antibody to hepatitis C virus, Canada, Hepatitis, Hepatitis C virus, Inuit, Liver disease, Non- $A$, non-B

\section{Prévalence des anticorps anti-hépatite $C$ dans un village inuit isolé}

RESUME: Le sérum de 720 habitants de Baker Lake, une communauté située dans les Territoires du Nord-Ouest et présentant de nombreux cas d'hépatite à virus A et B, a été analysé à la recherche d’anticorps contre le virus de l'hépatite $\mathrm{C}$ au moyen d'un test commercial d'immunoabsorption enzymatique. Seules, deux personnes sans lien de parenté (0,3\%) étaient positives, une femme de 63 ans et un garçon de dix ans. Ni l'un ni l'autre ne présentaient un risque supérieur d'exposition au virus de l'hépatite C. Les résultats de cette étude indiquent que l'hépatite à virus C n'est pas plus fréquente dans ce village inuit du Nord canadien que dans la population des donneurs de sang du Sud du Canada.

Departments of Medicine. Pharmacology and Medical Microbiology. University of Manitoba: and Health Sciences Clinical Research Centre, Winnipeg. Manitoba

Correspondence and reprints: Dr GY Minuk, Liver Diseases Unit. Health Sciences Centre, 820 Sherbrook Street, Winnipeg. Manitoba R3A 1R9. Telephone (204) 787-4662

Received for publication June 15, 1990. Accepted September 17. 1990 
$\mathrm{V}$ RAL HEPATITIS IS A COMMON HEALTH PROBLEM IN the Inuit population of northern Canada (1). Previous sero-epidemiological surveys have documented that approximately $80 \%$ of adults have been infected with the hepatitis A virus, and 25 to $35 \%$ have serologic evidence of either ongoing or previous hepatitis B virus infection (2-4). Hepatitis $\mathrm{D}$ virus infection has also been reported in the Canadian North; however, the true prevalence of this virus remains to be determined (5).

Recently, Choo and colleagues (6) reported the discovery of a single-stranded RNA virus responsible for the majority of cases of what had previously been referred to as non-A,non-B, hepatitis. The virus has since been designated hepatitis C. Preliminary data indicate that non-neutralizing antibodies to hepatitis $\mathrm{C}$ virus (anti-HCV) are present in the circulation of $80 \%$ of patients with parenterally acquired infection and $60 \%$ of patients with nonparenteral or sporadic forms of hepatitis $\mathrm{C}$ virus infection (7). The prevalence of anti-HCV in Red Cross blood donors living in southern Canada is approximately $0.5 \%$ (unpublished data)

To determine the prevalence of hepatitis $\mathrm{C}$ virus infection in a Canadian Inuit population, anti$\mathrm{HCV}$ antibodies were tested in stored sera from an isolated Inuit settlement where a high prevalence of hepatitis A and B virus infection had been previously documented (3).

\section{PATIENTS AND METHODS}

Study population: The geographic and demographic features of Baker Lake, Northwest Territories have been described in detail in previous publications $(3,8)$. Briefly, this is a prosperous settlement located 200 miles inland from the northwest coast of Hudson Bay. Sera were obtained in February 1980 when the population of the community was 850 . Approximately $95 \%$ of the inhabitants were Inuit and 5\% Caucasians. Informed consent to test blood samples for serologic evidence of viral hepatitis was obtained through a nursing station interpreter from all adults and parents or guardians of children involved in the study.

Laboratory methods: A total of 720 sera (85\% of the community's population) had been stored at $-70^{\circ} \mathrm{C}$ when first obtained. Thawing and refreezing of the samples had been confined to that required for hepatitis A and B viruses serologic testing. Anti-HCV was tested by an Ortho anti-HCV enzyme-linked immunosorbent assay (ELISA) test system which incorporates recombinant hepatitis $\mathrm{C}$ virus antigen (C100-3) into standard microtitre plates (7).

\section{RESULTS}

Of the 720 sera tested, only two $(0.3 \%)$ were positive for anti-HCV, a 63-year-old female and an unrelated 10-year-old male. Both individuals were Inuit. Neither had a history of hepatitis or drug abuse, nor had either received a blood or blood product transfusion in the past. The 63-year-old female was also positive for antibodies to hepatitis A virus and antibodies to hepatitis B surface and core antigens, but negative for hepatitis B surface antigen itself. The 10-year-old male was negative for serologic markers of both hepatitis A and B infection. Anti-HCV serology was also negative in the spouse and 13-year-old granddaughter living in the female's home and in the parents and four siblings living in the child's home.

\section{DISCUSSION}

Early epidemiological studies of non-A,non-B hepatitis revealed that transmission of this form of viral hepatitis could occur by either parenteral or nonparenteral routes (9). The most common forms of parenteral transmission for viral hepatitis include transfusions with blood or blood products, accidental needle stick injury, intravenous drug abuse, tattoos and scarification. Nonparenteral transmission occurs predominantly during maternal-infant exposure and sexual or intimate contact. Although not formally documented, the need for blood transfusions and the prevalence of parenteral drug abuse and tattooing are thought to be similar in the Canadian Inuit compared to populations living in southern Canada.

Scarification, which had been a common practice in the Inuit prior to the turn of the century, has essentially been abandoned for the past three to four decades. On the other hand, opportunities for nonparenteral transmission of hepatitis $\mathrm{C}$ virus are more common in the Inuit population. Indeed, previous sero-epidemiological surveys for hepatitis B virus infection revealed that hepatitis $B$ virus exposure is approximately five times more common in the Canadian Inuit than in southern Canadians, and that in this community the majority of infections occurred early in life, either via maternal-infant transmission at birth or during childhood (3).

Sexual transmission of infectious agents also occurs more frequently in northern native populations than in southern urban centres $(10,11)$. Thus the data derived from this study more accurately reflect the risk of nonparenteral rather than parenteral transmission of hepatitis $\mathrm{C}$ virus in the Canadian Inuit population compared to populations in the south.

The results of the present study indicate that despite increased opportunity for nonparenteral 
transmission, hepatitis $\mathrm{C}$ virus infection in this northern Inuit community is no more common than it is in southern Canada. Similar results documenting a low risk of transmission by sexual or intimate exposure have recently been reported in other populations and high risk groups (12).

As there were no identifiable risk factors for transmission of hepatitis $\mathrm{C}$ virus in the only two positive residents, infection in these two individuals may represent 'sporadic' cases or false-positive test results. False-positive results with ELISA testing for anti-HCV have been reported to occur with increased frequency in certain other diseases, particularly those associated with positive rheumatoid factor and/or hypergammaglobulinemia (13).

Unfortunately, an insufficient amount of sera was available to test for either of these possibilities or to submit for a confirmatory test which has recently been developed. Similarly, there was insufficient serum to document liver enzyme values, which would have served to determine whether

ACKNOWLEDGEMENTS: The authors thank Ms D Byron for her prompt and accurate typing of the manuscript. This work was supported by the Manitoba Medical Services Foundation (MMSF) and the Department of Northern Studies. Dr Minuk is the recipient of an MMSF professorship award.

\section{REFERENCES}

1. Larke RPB, Froese GJ, Devine RDO, Petruk MW. Extension of the epidemiology of hepatitis B in circumpolar regions through a comprehensive serologic study in the Northwest Territories of Canada. J Med Virol 1987;22:269-76.

2. Minuk GY, Waggoner JG, Jernigan R, Nicolle LE, Postl B. Hoofnagle JH. Prevalence of antibody to hepatitis A virus in a Canadian Inuit community. Can Med Assoc J 1982; 127:850-2.

3. Minuk GY, Nicolle LE, Postl B, Waggoner JG. Hoofnagle $\mathrm{JH}$. Hepatitis virus infection in an isolated Canadian Inuit (Eskimo) population. J Med Virol 1982;10:255-65.

4. Minuk GY, Ling N, Postl B, Waggoner JG, Nicolle LE, Hoofnagle JH. The changing epidemiology of hepatitis B virus infection in the Canadian North. Am J Epidemiol 1985;121:598-604.

5. Cheng HH, Wang D, Minuk GY, Anand CM, Stowe TC, Buchan KA. The prevalence of antibody to delta virus in western Canada. Clin Invest Med 1986:9:156-9.

6. Choo QL, Kuo G, Weiner AJ, Overby LR, Bradley DW. Houghton M. Isolation of a cDNA clone derived from a blood-borne non-A, non-B viral hepatitis genome. Science 1989:244:359-62.

7. Kuo G, Choo QL, Alter HJ, et al. An assay for circulating antibodies to a major etiologic virus of human non-A, non-B hepatitis. Science 1989;244:362-4. hepatocellular disease consistent with hepatitis C virus infection was present.

The essential finding of this study is that, unlike hepatitis $\mathrm{A}$ and $\mathrm{B}$ viruses, hepatitis $\mathrm{C}$ virus infection is uncommon (or perhaps absent altogether) in this northern Inuit settlement. Why it is less common than other forms of viral hepatitis remains to be determined. It is possible, since some hepatitis viruses such as hepatitis D virus migrate from one geographical area to another (14), that hepatitis C virus has not yet been introduced to the Canadian north. Alternatively, infections with this agent may have declined spontaneously in recent years, as has been described for hepatitis $B$ virus infection in certain endemic areas $(4,15)$.

In summary, only two of 720 individuals $(0.3 \%)$ of an isolated Inuit settlement with a high prevalence of hepatitis A and B viruses tested positive for anti-HCV. These data indicate that hepatitis C virus is not a common health problem in this population at this time.

8. Nicolle LE, Postl B, Kotelewetz E, et al. Nasopharyngeal carriage of Neisseria meningitidis and Hemophilus influenzae in a Canadian Arctic community. In: Harvald B, Hansen JPH, eds. Proceedings of the 5th International Symposium on Circumpolar Health. Copenhagen: Nordic Council for Arctic Medical Research, 1981.

9. Dienstag JL. Non-A, non-B hepatitis. I. Recognition, epidemiology, and clinical features. Gastroenterology 1983;85:439-62.

10. Muri D, Blackwood L. Gonorrhea reinfection rate in an Alaska native population. In: Harvald B, Hansen JPH, eds. Proceedings of the 5th International Symposium on Circumpolar Health. Copenhagen: Nordic Council for Arctic Medical Research, 1981.

11. Skinhoj P. Persistent virus infections in the Arctic. In: Fortuine R, ed. Proceedings of the 6th International Symposium on Circumpolar Health. Anchorage: University of Washington Press, 1984

12. Everhart JE, Di Bisceglie AM, Alter H, et al. Elevated serum alanine aminotransferase activities among sexual partners and household contacts of persons with nonA nonB hepatitis. Hepatology 1988;8:1270. (Abst)

13. McFarlane IG, Smith HM, Johnson PJ, Bray GP, Vergani D, Williams R. Hepatitis C virus antibodies in chronic active hepatitis: Pathogenic factor or false positive result. Lancet 1990;i:754-7.

14. Ponzetto A, Forzani B, Parravicini PP, Hele C, Zanetti A. Rizzetto M. Epidemiology of hepatitis delta virus (HDV) infection. Eur J Epidemiol 1985; 1:257-63.

15. Kashiwagi S, Hayashi J, Ikematsu H, et al An epidemiologic study of hepatitis B virus in Okinawa and Kyushu, Japan. Am J Epidemiol 1983; $118: 787-94$ 


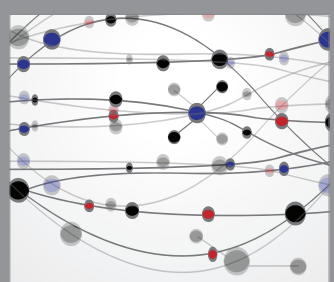

The Scientific World Journal
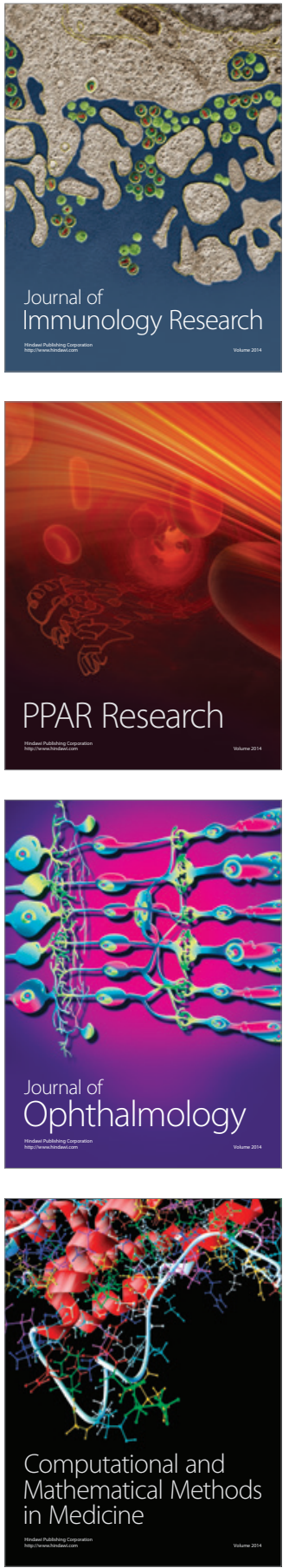

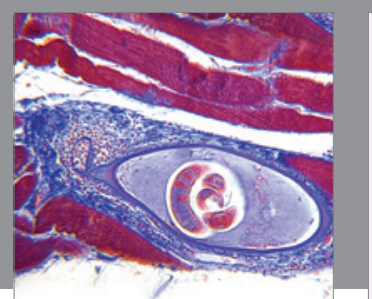

Gastroenterology Research and Practice

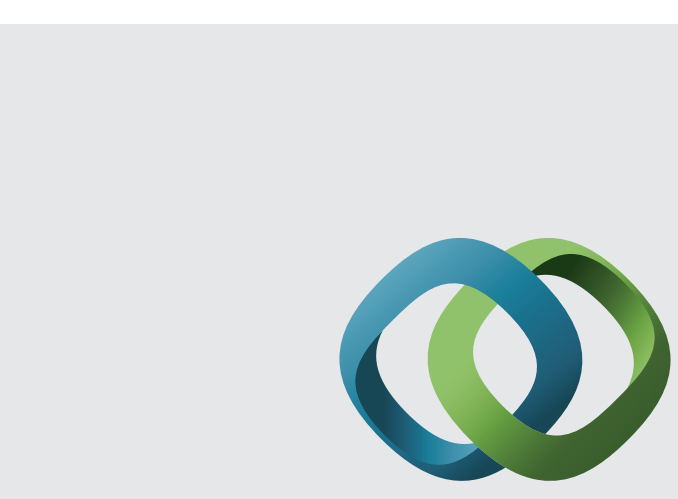

\section{Hindawi}

Submit your manuscripts at

http://www.hindawi.com
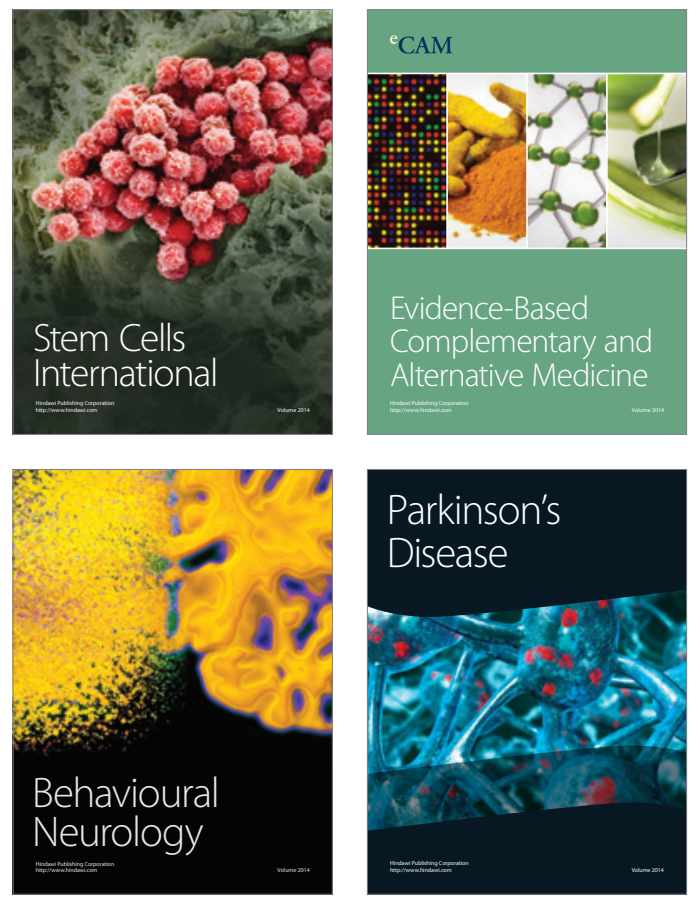
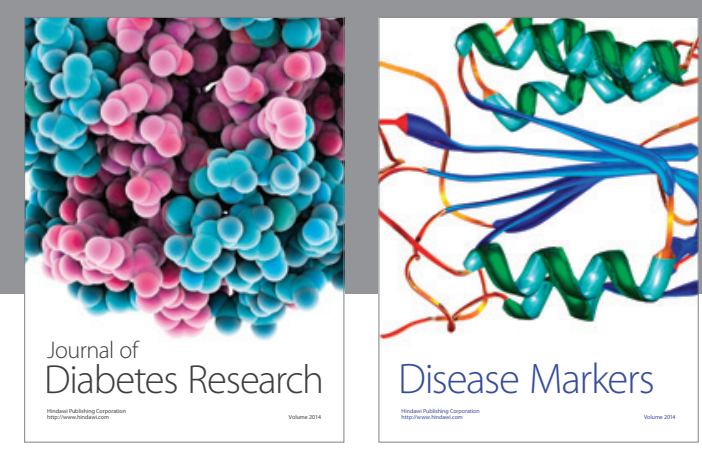

Disease Markers
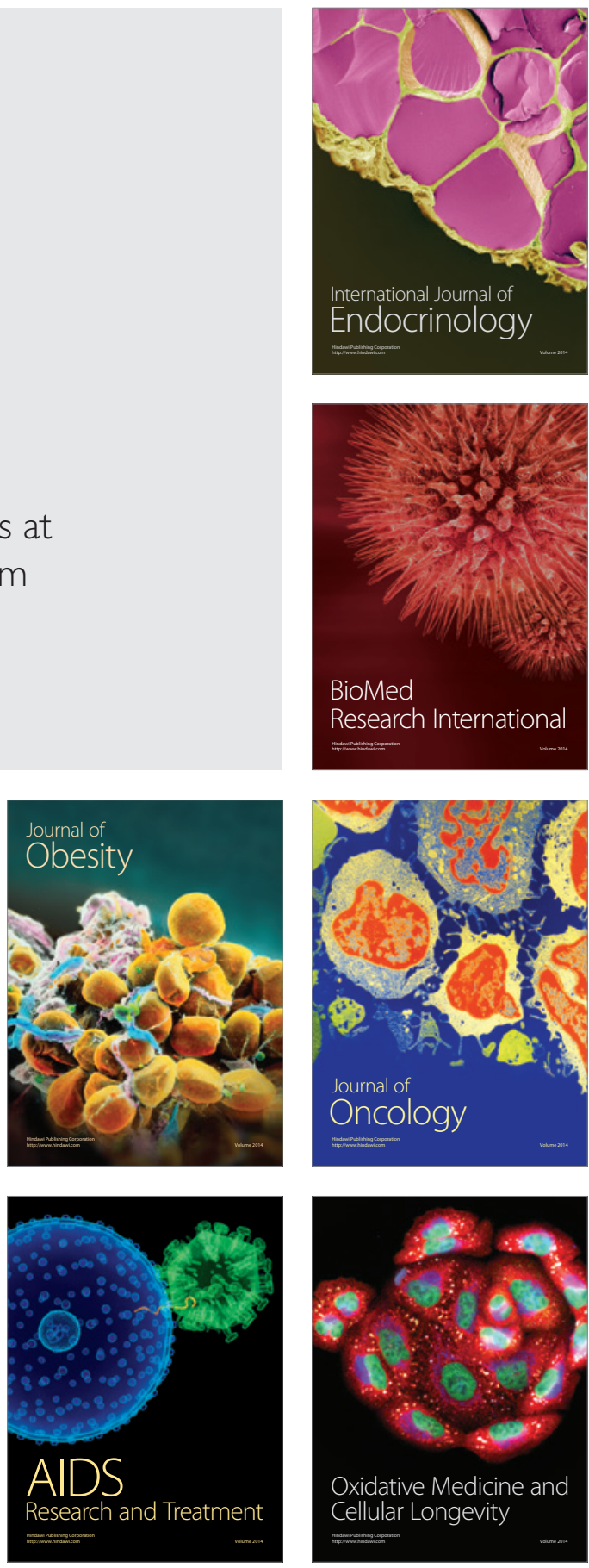